Article

\title{
High-Throughput Microfiltration Membranes with Natural Biofouling Reducer Agent for Food Processing
}

\author{
Panggulu Ahmad R. Utoro ${ }^{1}$, Agung Sukoyo ${ }^{1}$, Sandra Sandra ${ }^{1}$, Nimatul Izza ${ }^{2}$, \\ Shinta Rosalia Dewi ${ }^{2}$ and Yusuf Wibisono ${ }^{2,3, *(\mathbb{D})}$ \\ 1 Department of Agricultural Engineering, Brawijaya University, Malang 65145, Indonesia; \\ pangguluahmad859@gmail.com (P.A.R.U.); ohmagung@gmail.com (A.S.); sandra.msutan@ub.ac.id (S.S.) \\ 2 Department of Bioprocess Engineering, Brawijaya University, Malang 65145, Indonesia; \\ izza_nimatul@ub.ac.id (N.I.); shintarosalia@ub.ac.id (S.R.D.) \\ 3 MILI Water Research Institute, P.O. Box 301 ML, Malang 65101, Indonesia \\ * Correspondence: Y_Wibisono@ub.ac.id; Tel.: +62-341-571-708
}

Received: 26 October 2018; Accepted: 17 December 2018; Published: 20 December 2018

\begin{abstract}
The effect of natural antibiotics Moringa oleifera seeds powder in cellulose acetate membranes as biofouling reducer agent was investigated. Mixed matrix membranes (MMM) were synthesized by adding 100 mesh $M$. oleifera seeds powder with variation of three concentrations $(1 \mathrm{wt} \%, 2 \mathrm{wt} \%$, and $3 \mathrm{wt} \%$ ), into a mix polymer solution of CA (cellulose acetate) and two different solvents, i.e., DMF (dimethylformamide) and DMAc (dimethylacetamide). The synthesized membranes morphology was observed under scanning electron microscopy and from the images can be seen that the membranes made of DMAc formed rather large macrovoid as compared to DMF-based membranes. The microstructure affected the water flux through the membranes, in which the DMAc membranes provided a higher flux value and served as high-throughput microfiltration membranes. Antibacterial properties of MMM were tested using Escherichia coli adhesion onto membrane surfaces. The results showed that $M$. oleifera has been proven to eradicate E. coli activity on the membrane surfaces due to interaction between bacterial cells and phenolic compounds from M. oleifera, through absorption processes involving hydrogen bonds.
\end{abstract}

Keywords: mixed matrix membrane; cellulose acetate; microfiltration; biofouling; Moringa oleifera

\section{Introduction}

Membrane filtration is a promising technology for the separation of subtances, whether for aqueous or gas separation application [1]. Microfiltration and ultrafiltration, for instance, are widely used for food processing and separation of macromolecules, such as for fruit juice clarification. Fruit juice clarification processes aiming at reducing the dissolved solids in the fluid, and it is able to produce clearer juice or liquid. Membrane-based ultrafiltration processes were utilized to process orange and lemon juices [2], pineapple juice [3], and kiwi juice [4].

Application of membrane filtration for food processing, however, also suffered by deposited particles, either organic, inorganic, or biological substances, on the membrane surface, called fouling. Several attempts existed for controlling fouling, from physical cleaning using turbulence-induced flow [5,6] to surface-engineered membranes or feed spacers [7].

Adapting the membrane morphology to improve specific properties, such as anti-biofouling, is not only possible by modifying the membrane surface but also by optimizing inner structure. Mixed matrix membranes (MMM) developed to achieve the formation of asymmetric membrane by interpenetrating functionalized inorganic particles and a polymeric matrix [8,9]. By employing MMM, 
two or more different properties of components combined, to achieve a better separation performance. In order to promote antifouling properties, some combination of functionalized fillers and polymer matrixes have been used, such as a combination of nanoparticles of anatase $\mathrm{TiO}_{2} /$ polysulfone [10] and Ag-loaded graphene oxide/polyethersulfone [11]. Those combination were effective, however the use of metal components as fillers, e.g., silver particles, might be unsafe for membrane that is used for food processing application. The use of plant-based subtances, might provide a more reliable and safe anti-biofoulant, such as the utilization of cardanol [12]. In this study, a natural antibacterial $M$. oleifera seeds powder is evaluated to be employed as filler to the cellulose acetate polymer matrix to form anti-biofouling MMM.

M. oleifera could be utilized against Gram positive and negative bacteria [13]. Recombinant protein inside M. oleifera seeds is able to agglomerate Gram positive and negative bacterial cells [14]. By its properties, Moringa seeds could potentially be used as for environmentally friendly antibiofouling, because these natural ingredients are not harmful, even if used in large quantities when compared with chemicals or metals that are commonly used as agents to reduce biofouling.

As for polymeric matrix, cellulose acetate has been chosen due to some beneficial properties. Cellulose acetate has good properties as a membrane polymer for food processing due to renewable, biodegradable, biocompatible, non-toxic, and inexpensive subtances $[15,16]$. Cellulose acetate has relatively thermal and chemical stability [17], because cellulose has a rich of hydroxyl groups and it is able to form a strong hydrogen bonds that could not be separated easily [18]. Cellulose acetate are also extraordinary hydrophilic, which can be used for minimizing fouling on the membrane $[19,20]$. By its higher hydrophilicity, the cellulose acetate has the potential as an ultrafiltration membrane material, because it has ability pass water efficiently. On the other hand, cellulose acetate membranes have a drawback, namely the lack of a reactive functional group on the polymer surface, which might degrade the efficiency of membrane separation [21]. In this study, the use of cellulose acetate as polymeric matrix and impregnated $M$. oleifera seeds powder is aiming at the enhancement of membrane permeability and selectivity. The future direction of this study is the used of non-toxic and anti-biofouling M. oleifera particles filled in the hydrophylic cellulose acetate matrix to form MMM for juice clarification.

\section{Materials and Methods}

\subsection{Materials}

M. oleifera (Mo) seeds were provided by a local farmer in Indonesia. M. oleifera seeds was dryed by using oven at $60^{\circ} \mathrm{C}$ for $24 \mathrm{~h}$. The seeds were grinded into 100 mesh of powder size. In order to obtain a uniform M. oleifera powder size, the powder was analyzed by using CILAS 1090 (CILAS, Orleans, France) particle size analyzer. Moreover, because the phenolic substances are recognized as promoting anti-bacterial activity, the M. oleifera seeds powder was characterized using a Fourier-transform infrared spectroscopy (FT-IR) Shimadzu 8400S (Shimadzu Corp., Kyoto, Japan) to investigate its phenolic contents. All chemicals and reagents that were used in this research are of analytical grade (pure analysis, pa). Cellulose acetate (CA), dimethylformamide (DMF), dimethylacetamide (DMAc) were purchased from Merck (Darmstadt, Germany). The concentration variation of cellulose acetate, M. oleifera powder and solvents are modified from Saranya et al. [22] and full factorial design of experiment were used and summarized in Table 1. Each treatment was repeated three times.

\subsection{Mixed Matrix Membranes Preparation}

Every combination of polymer, Moringa powder, and solvents shown in Table 1 were mixed manually using laboratory spatula due to viscous mixture, until homogen. The mixture was then left for $24 \mathrm{~h}$ until there is no bubbly gas left. The membrane solution is then casted by using custom made casting knife in designated thickness and constant casting speed to form the uniform membrane 
sheet. The casted polymer is then immersed in distilled water for $10 \mathrm{~min}$, which allows the membrane solidify. The MMM's sheets were then dried in a box under slow, modest, and constant nitrogen flow.

Table 1. Mixture of M. oleifera, cellulose acetate and solvents (dimethylformamide (DMF) or dimethylacetamide (DMAc)) used in this study.

\begin{tabular}{cccccc}
\hline Treatment & CA (g) & Mo (g) & CA + Mo (g) & DMF (mL) & DMAc (mL) \\
\hline CA + DMF (Pristine DMF) & 4 & - & 4 & 20 & - \\
CA + 1 wt\% Mo + DMF & 3.96 & 0.04 & 4 & 20 & - \\
CA + 2 wt\% Mo + DMF & 3.92 & 0.08 & 4 & 20 & - \\
CA + 3 wt\% Mo + DMF & 3.88 & 0.12 & 4 & 20 & - \\
CA + DMAc (Pristine DMAc) & 4 & - & 4 & - & 20 \\
CA + 1 wt $\%$ Mo + DMAc & 3.96 & 0.04 & 4 & - & 20 \\
CA + 2 wt $\%$ Mo + DMAc & 3.92 & 0.08 & 4 & - & 20 \\
CA + 3 wt\% Mo + DMAc & 3.88 & 0.12 & 4 & - & 20 \\
\hline
\end{tabular}

\subsection{Membranes Thickness Measurement}

It is essential to know the thickness of the membranes that has been made. Membrane thickness and tortuosity will affect the transport of liquid through the membrane and also affect filtration time. Measurement of membrane thickness were done on five locus, i.e., top, bottom, right, left, and middle edges of membrane sheets by using a micrometer with an accuracy of $0.01 \mathrm{~mm}$. The data obtained were then averaged.

\subsection{Membranes Morphology}

The Scanning Electron Microscope (SEM) images provide morphology of inner side of the membranes, i.e., membrane pores and macrovoid. Cross section of the MMM were analyzed by using SEM JEOL JSM-6360 (JEOL Ltd., Tokyo, Japan), with accelerating voltage of $10 \mathrm{kV}$. The samples were coated with Pd-Au prior to SEM investigation.

\subsection{Tensile Strength and Elasticity}

The testing of tensile strength and elasticity are necessary to evaluate the physical characteristics of the membrane that has been made. The mechanical properties will affect the physical strength of the sheet to withstand the pressure given during the filtration process. Physical characteristics of membranes were tested using tensile strength Imada ZP-200N (Imada Co. Ltd., Toyohashi, Japan).

\subsection{Flux Test}

To determine the ability of membrane performance, the flux value was investigated. The flux is basically the mass transfer occurred during the filtration processes and it is related to membrane permeability. Pristine CA membranes (membranes without M. oleifera seeds powder) and MMM's (membranes with $M$. oleifera seeds powder) were tested under dead-end operation mode under 0.7 bar constant transmembrane pressure. The diameter of the membrane tested was $3 \mathrm{~cm}$, and the duration of the test was $10 \mathrm{~min}$, which measured the volume of permeate every $1 \mathrm{~min}$. Flux was measured from amount of water volume passing through each unit of membranes area per unit time.

\subsection{Anti-Bacterial Test}

The bacterial cultivation and antibacterial test were undertaken following methods used previously [23,24]. The adhered bacterial cells on each membrane surfaces were observed by using SEM Hitachi TM3000 (Hitachi, Ltd., Tokyo, Japan). The bacterial cells attachment test was done for the individual sample from pristine and $1 \mathrm{wt} \%$ membrane samples. 


\section{Results}

\subsection{Moringa Oleifera Seeds}

\subsubsection{Physical Characteristics}

The physical appearance of $M$. oleifera seeds before peeling, after being peeled and after being powdered can be seen in Figure 1. As shown in Figure 1, M. oleifera seeds has black and hard shells before peeled (a) and the white seeds were obtained after being peeled (b). The powdered M. oleifera seeds after grinded (c) and meshed of 100 mesh or about $149 \mu \mathrm{m}(\mathrm{d})$, looks more delicate and has a more uniform texture when compared to (c).

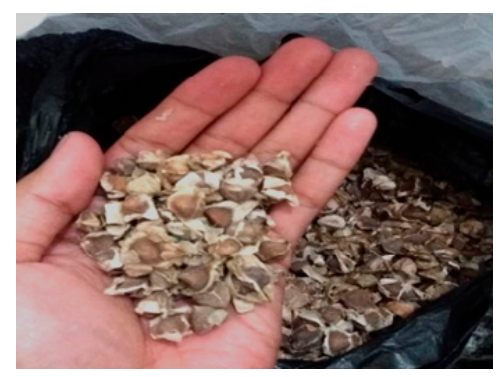

(a)

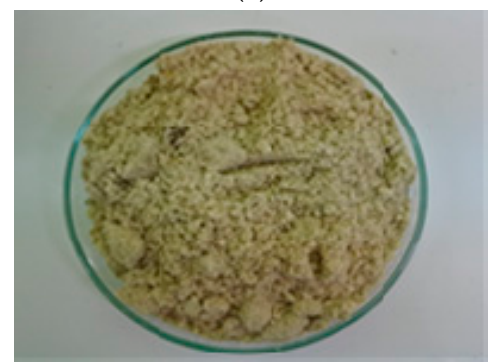

(c)

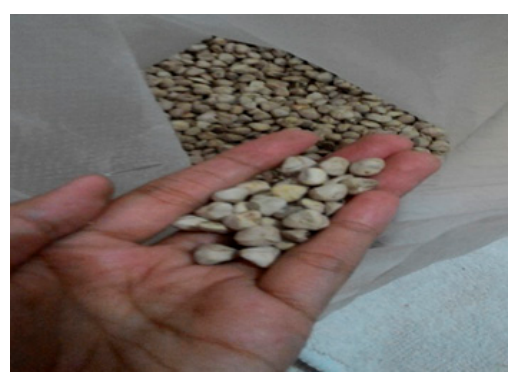

(b)

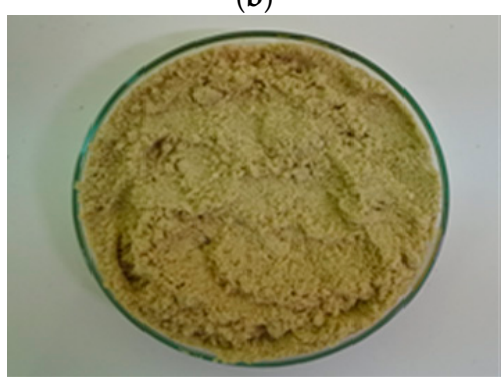

(d)

Figure 1. (a) M. oleifera seeds before peeling with hard and black shells, (b) M. oleifera white seeds after peeling, (c) M. oleifera seeds after powdered, and (d) M. oleifera seeds 100 mesh (about $149 \mu \mathrm{m}$ ).

In order to obtain a more details on the M. oleifera powder size distribution, the powder was analized using a particle size analyzer and the results shown in Figure 2.

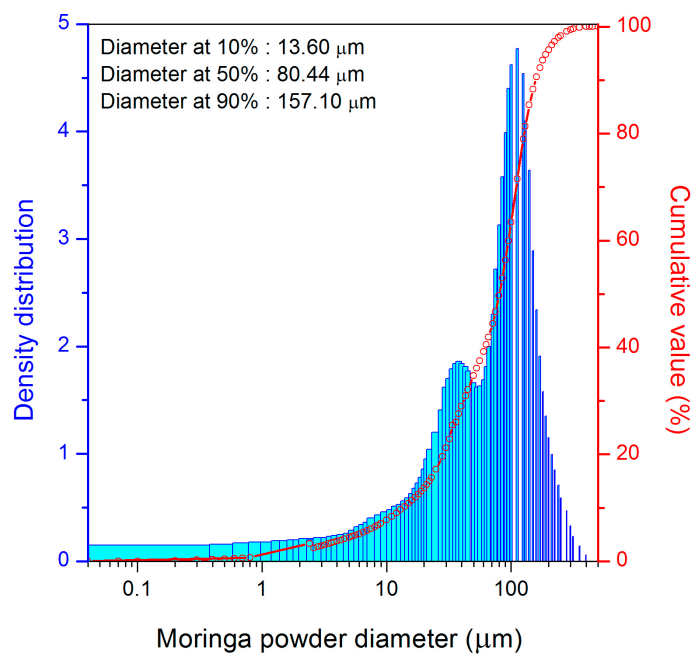

Figure 2. M. oleifera powder diameter distribution as measured by particle size analyzer. The density distribution shown in blue, while cumulative percentage shown in red. 
As shown in Figure 2, the M. oleifera powder diameter distribution are $10 \%$ on the size of $13.60 \mu \mathrm{m}$, $50 \%$ on the size of $80.44 \mu \mathrm{m}$, and $90 \%$ on the size of $157.10 \mu \mathrm{m}$. It is concluded that the most M. oleifera powder basically has average diameter of about $157 \mu \mathrm{m}$, and it has relatively uniform size based on the histogram shown.

\subsubsection{Chemical Composition}

Chemical compounds of $M$. oleifera seeds powder were characterized by using FT-IR. The spectra image can be seen in Figure 3, along with the spectra of M. oleifera extract previously reported [25,26], as comparison.

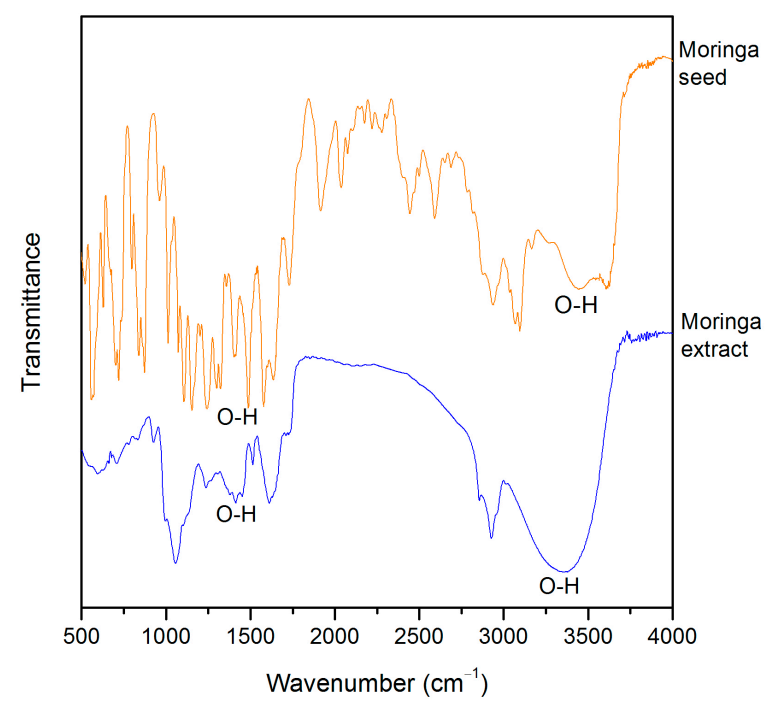

Figure 3. Fourier-transform infrared (FT-IR) spectra of M. oleifera seeds powder and extract, show the presence of hydroxyl groups of phenolic compounds.

From the spectra, it can be seen that $M$. oleifera seeds contain phenolic compounds, which are detected at the peak of hydroxyl groups $(-\mathrm{OH})$ at 1379.77 and 3321.96 . The IR spectra of $M$. oleifera extract shows a more clear peaks, while the M. oleifera seed powder shows a more noisy spectra due to the presence of another subtances. However, both spectra show peaks of hydroxyl group of phenolic and alcoholic compounds. The complete compounds of M. oleifera seeds powder are listed in Table 2.

Table 2. FT-IR Peak of M. oleifera Seeds Powder.

\begin{tabular}{ccc}
\hline Peak $\left(\mathbf{c m}^{-\mathbf{1}}\right)$ & Functional Group & Name \\
\hline 986.32 & $\mathrm{C}=\mathrm{C}$ & Alkene \\
1057.68 & $\mathrm{C}-\mathrm{O}$ & Primary Alcohol \\
1237.05 & $\mathrm{C}-\mathrm{O}$ & Alkyl Aryl Ester \\
1269.84 & $\mathrm{C}-\mathrm{O}$ & Aromatic ester \\
1379.77 & $\mathrm{O}-\mathrm{H}$ & Phenol \\
1746.22 & $\mathrm{C}=\mathrm{O}$ & Ester \\
2689.35 & $\mathrm{C}-\mathrm{H}$ & Aldehyd \\
2924.65 & $\mathrm{C}-\mathrm{H} / \mathrm{N}-\mathrm{H}$ & Alkene/Amine Salt \\
3321.96 & $\mathrm{O}-\mathrm{H}$ & Alcohol \\
\hline
\end{tabular}

Phenolic compounds could act as antibacterial agent. The utilization of M. oleifera as a natural coagulant within filtration process could eliminate cyanobacterial and microcystin [27]. A previous study reported that ten phenolic compounds found inside M. oleifera seeds extract i.e., gallic acid, p-coumaric acid, ferulic acid, caffeic acid, catechin, epicatechin, vanillin, and quercetin [28]). M. oleifera seeds have natural phenolics, which are a good source for natural antioxidants and antibacterials for 
pharmacy and food processes. It is therefore M. oleifera seeds that also can be used as a biofouling reducing agent in MMMs for food processing.

\subsection{Mechanical Properties of the Membranes}

The physical appearance of cellulose acetate membranes with $M$. oleifera seeds filler was thin and white-colored sheet. There was no difference in color between MMM and pristine membranes, which means that $M$. oleifera seeds powder did not affect the color of the membranes.

The visible surface morphology between membranes used of DMF solvent and used of DMAc solvent were also no different. These two solvents provided a good morphological surface of the membranes. It has been approved that the solubility of cellulose acetate polymer is suitable for both solvents that were used in this research, based on Brandup criteria [29].

\subsubsection{Membranes Thicknesses}

The average thickness of the membranes are presented in Figure 4. As mentioned previously, membrane thickness and tortuosity were essential on liquid transport inside the membranes. The thickness affects the filtration time, and might also alter the performance of membrane filtration processes [30].

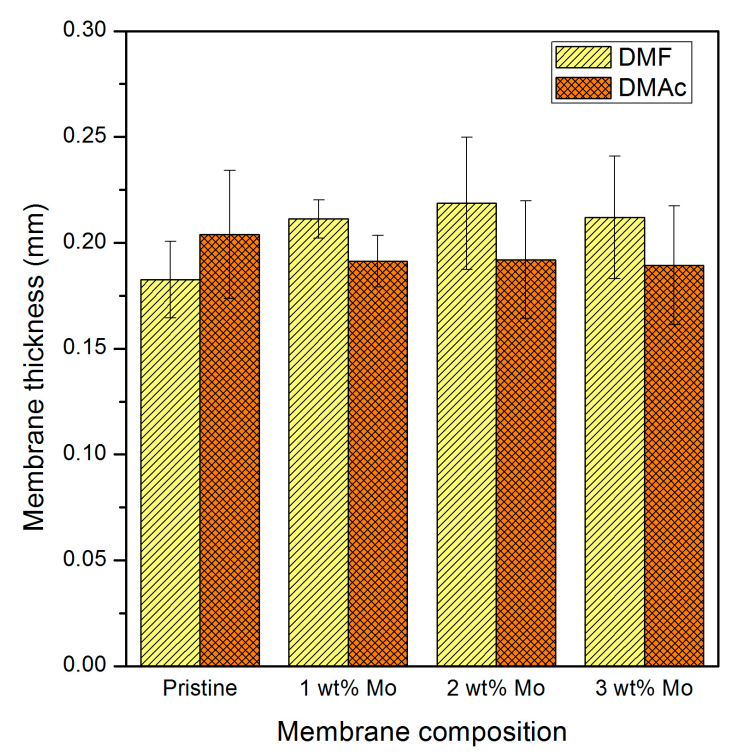

Figure 4. Average membrane thicknesses based on different materials composition.

Based on Figure 4, it can be seen that there were a small difference on average membrane thickness between the membranes made of DMF and DMAc solvents. The largest range of MMMs thickness was $0.03 \mathrm{~mm}$. The membranes thickness decreased after drying due to solvent evaporation. The rate of solvent evaporation will affect the thickness of the membrane produced. The longer time it takes for the solution to evaporate, the thicker membrane sheet and the lower porosity produced. The pristine membrane made of DMF solvent has thinner sheet when compared with the pristine membrane made of DMAc solvent. By the addition of the Moringa seeds powder, the MMM is made of DMF solvent that is thicker than that of DMAc. However, the thicknesses of the membranes were relatively uniform.

\subsubsection{Membrane Sheets Tensile Strength and Elasticity}

Tensile strength and elasticity were tested to understand the physical properties of each membrane sheets and the results are shown in Figure 5. As shown, there was a slightly different tensile strength values between MMMs that dissolved in DMF and DMAc. The tensile strength value of MMMs in DMF solvent was a bit lower than MMMs in DMAc solvent by increasing the M. oleifera seeds 
concentration. The increased value might be affected by the more tight structure of membranes that are made by DMAc solvent. The membrane structure promoted by the solubility of cellulose acetate polymer in DMAc solvent is lower when compared to DMF.

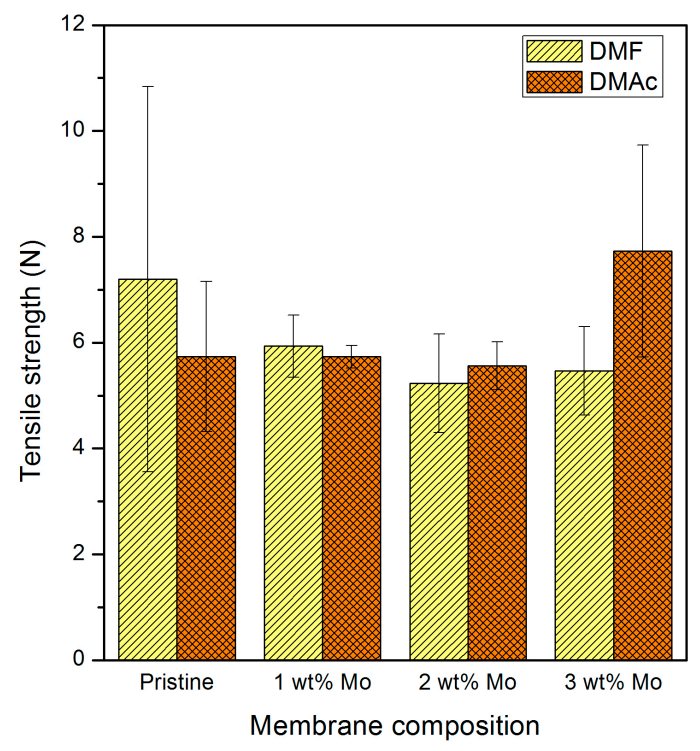

Figure 5. Tensile strength of the membrane sheets provide a mechanical strength of the membranes.

On the other hand, as shown in Figure 6, the elasticity of both membranes increased with the addition of M. oleifera seeds powder, but then decreased and levelled off at $10 \%$ and $11.11 \%$.

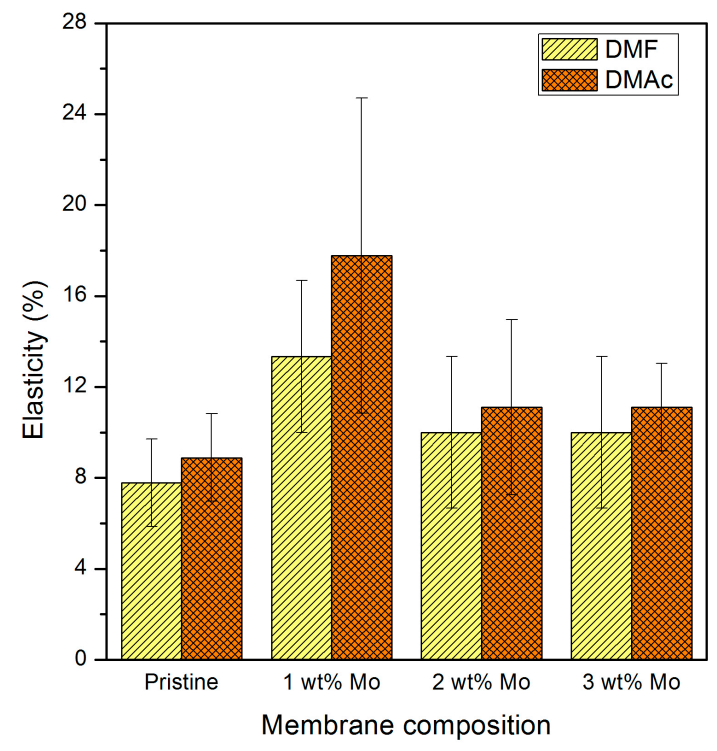

Figure 6. Membrane sheet elasticity based on various materials composition.

In general, both membrane sheets tensile strength and elasticity are affected by the use of solvents. However, the mechanical properties of the membranes are similar, this is because the DMF and DMAc solvents have almost the same properties. Both solvents are polymetric, have a low evaporation point, and have strong hydrogen bonds [31]. Although membranes that are made of DMF solvents and membranes made of DMAc solvents have almost the same properties, but the DMF's is always slightly better in both physical and chemical properties [32].

The addition of $M$. oleifera seeds powder can increase the membrane elasticity, especially with the addition of $1 \mathrm{wt} \%$ M. oleifera seeds powder in the membrane that is made of DMAc solvent. This is due 
to a strong hydrogen bonding between cellulose acetate and DMAc [33]. However, after the addition of $2 \mathrm{wt} \%$ M. oleifera seeds powder, its elasticity decreased. Adnan, et al. [34] reported that with addition of silica as filler in CA membrane, promote the decrease of mechanical properties. It could be caused by aggregation of particles due to a higher concentration and prevent it to disperse uniformly in a polymer matrix.

\subsection{Membrane Pores and Morphology}

Pores of membranes affect membrane permeability. The SEM cross-section images of the membrane sheets are shown in Figure 7. As shown, we can distinguished the pores size between control membranes both in DMF and DMAc solvents. Besides, it can be seen that there are a lot of selective layers (small pores located in the upper layer) on CA membranes with $1 \mathrm{wt} \%$ Moringa seeds powder in the DMAc solvent. The structure promotes membrane permeability of DMAc solvent better than membranes using DMF solvent.

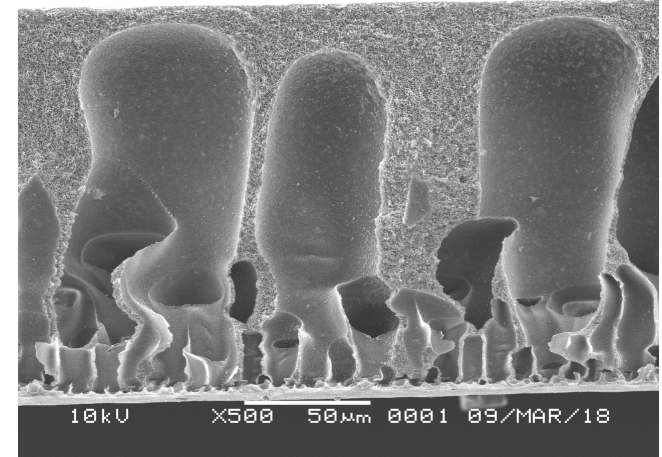

(a)

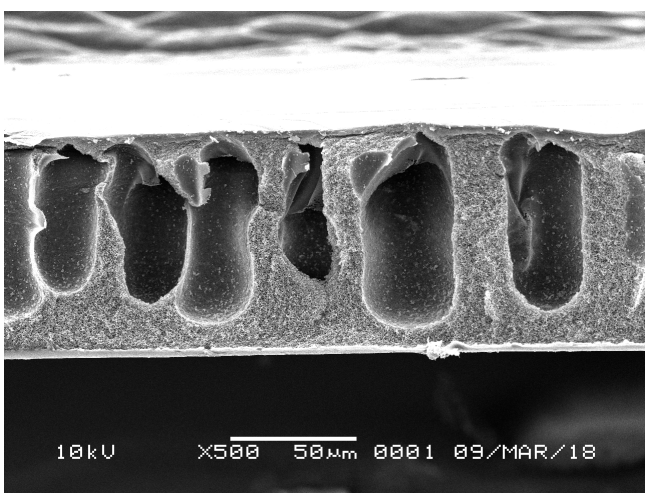

(c)

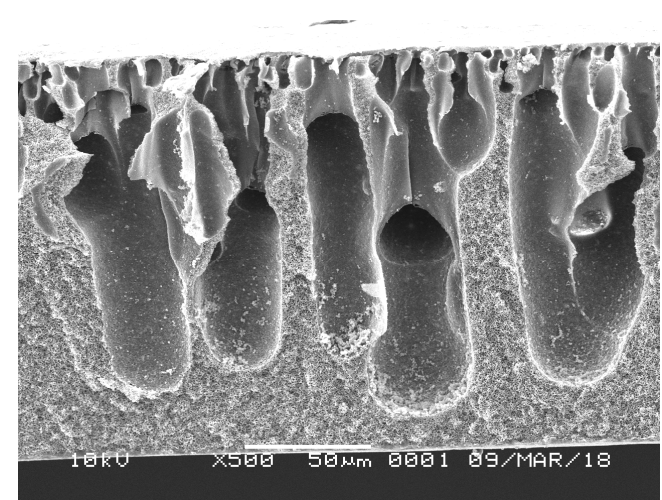

(b)

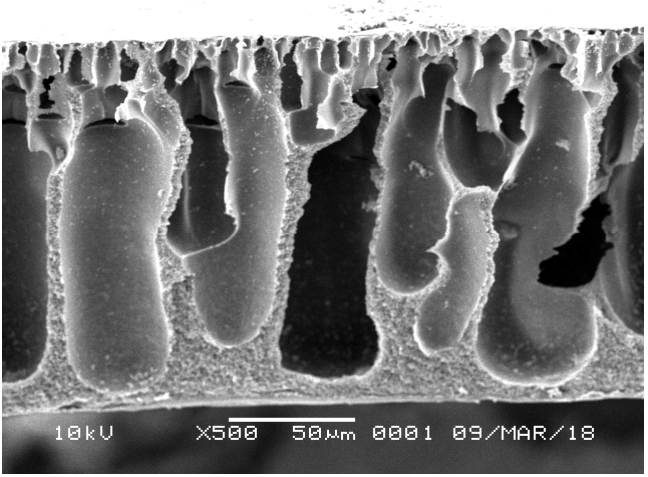

(d)

Figure 7. Cross-Section SEM images (500× magnification): (a) cellulose acetate (CA) pristine membrane made of dimethylformamide (DMF) solvent, (b) CA mixed matrix membranes (CA MMM) with $1 \mathrm{wt} \%$ Moringa seeds powder made of DMF solvent, (c) CA pristine membrane made of DMAc solvent, and (d) CA MMM with $1 \mathrm{wt} \%$ Moringa seeds powder made of DMAc solvent.

The DMAc solvent is more effective in dissolving cellulose acetate due to DMAc solubility that is nearly close to cellulose acetate solubility. The difference of solubility $(\Delta \delta)$ between DMAc and cellulose acetate is $2.14 \mathrm{MPa}^{1 / 2}$, while DMF and cellulose acetate is $4.84 \mathrm{MPa}^{1 / 2}$ [29]. If the solubility parameter between the polymer and solvent were close, then the mixing will be better. Solubility is closely related to the density of cohesive energy needed in the phase of polymer separation with solvents [35], where the solubility parameter is translated as the root function (rank $\frac{1}{2}$ ) of the cohesive energy density, which is then known as HSP (Hildebrand Solubility Parameter) [36]. By this approach, the solubility between polymers and solvents can be predicted [35]. The polymer-solvent interaction is affected by 
the enthalpic and entropic components of the materials [37]. Materials which have similarities in HSP will be easily mixed or dissolved [38]. Based on the aforementioned, the difference in solubility of DMAc with solubility of cellulose acetate is smaller than that of DMF. The cohesive energy density is also related to molecular weight, where the higher molecular weight, the smaller frequency of coherent energy needed [35]. The molecular weight of DMAc used in this study was $87.12 \mathrm{~g} \cdot \mathrm{mol}^{-1}$, while DMF was $73.09 \mathrm{~g} \cdot \mathrm{mol}^{-1}$. It is reported that the preparation of membranes cellulose acetate-polysulfone via the phase inversion method produces higher pores, however, with increasing the additive materials, pores will decrease [39]. In this work, on the other hand, CA membrane with $1 \mathrm{wt} \% \mathrm{M}$. oleifera seeds powder made of DMAc solvent produce many pores than that of made of DMF solvent.

\subsection{Effect of Adding M. oleifera Seeds Powder on Membrane Flux}

This flux value shows the membrane's ability to pass fluid to the filtration process and is related to the permeability of the membrane. The clean water flux values for each membrane can be seen in Figure 8. Membranes that are made of DMAc solvent had higher flux values than that of the DMF solvent. It was clear that the addition $M$. oleifera seeds powder increased the flux membranes made of DMAc solvent. In DMF solvent, the flux of MMMs decreased $44 \%$ after adding $1 \mathrm{wt} \%$ M. oleifera seeds powder. This phenomena might have occurred due to more macrovoid on the mixed matrix membranes with DMAc solvent, along with the addition of Moringa seeds powder, as compared with the ones of DMF solvent. The SEM images shown previously in Figure 7 were supported the evidence. By the flux value, the membranes produced could be considered as high-throughput microfiltration membranes [30].

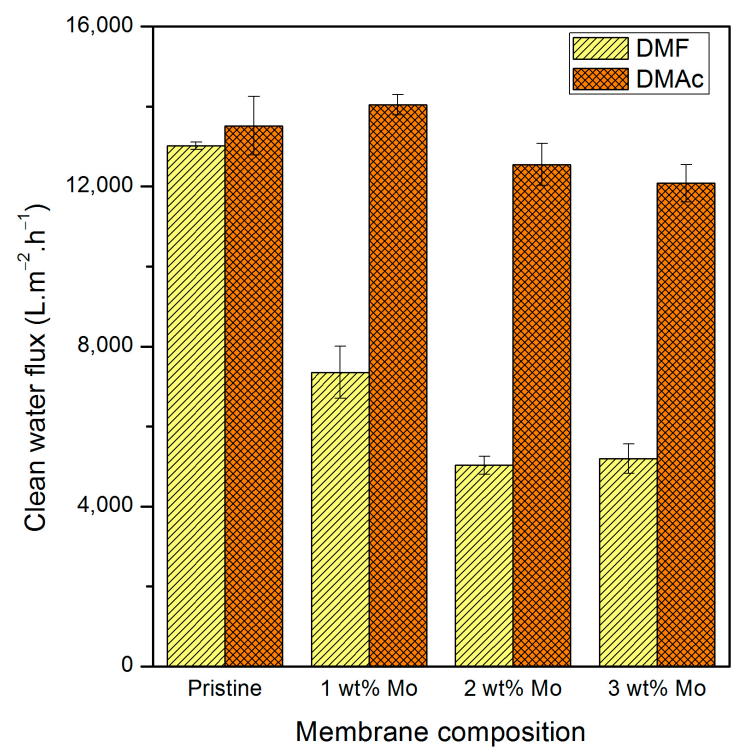

Figure 8. Clean water flux as measured for each membrane.

Previous studies reported the preparation of high flux microfiltration membranes. Ferreira et al. [40] produced high flux microfiltration membranes with the flux value up to $11,017 \mathrm{~L} \cdot \mathrm{m}^{-2} \cdot \mathrm{h}^{-1}$, used polyethersulfone (PES) and DMAc with silver nanoparticles for water disinfection. The membranes manufactured formed a sponge-like structure. However, the flux was decreased by changing the composition of polymer and solvent and changing the precipitation bath between solvent and water. The later treatment was affected in membrane pores, which were formed. In this study, flux values of MMMs tht were made of DMAc solvent are higher than that of DMF solvent. This is because MMMs that are made of DMAc solvent has more macrovoid pores than that of DMF solvent, as clearly shown by SEM images in Figure 7. 
The highest value of flux is found on membranes made of DMAc solvent with the addition $1 \mathrm{wt} \%$ M. oleifera seeds powder. Flux values decreased significantly due to the increasing concentration of $M$. oleifera seeds powder to the mixed materials. The same result was obtained in a different study [41], with their work on of high flux polysulfone membranes. Another research was done and reported that high flux membranes were produced, and testing the performance in a constant flux test [42]. Several microfiltration and ultrafiltration industrial membranes were tested. The high flux $\left(900-4000 \mathrm{~L} \cdot \mathrm{m}^{-2} \cdot \mathrm{h}^{-1}\right)$ affinity membranes based on cellulose nanocomposites for removal heavy metal ions from industrial effluents were also reported [43].

\subsection{Effect of Adding M. oleifera on Bacterial Activity}

The effect of adding natural antibacterial subtances from $M$. oleifera seeds evaluated by the adhesion of E. coli bacteria cells onto membrane surfaces. The SEM images are presented in Figure 9. The addition of M. oleifera seeds powder as antibacterial material on MMM surfaces in both DMF and DMAc solvents provided a significant effect. When comparing the pristine membrane and MMM, the pristine membrane attract E. coli bacteria cells adhered on its surface area. On the other hand, MMM membranes, which are both made of DMF or DMAc solvents, had less bacteria attachment on its surfaces. Detailed quantification of bacterial attachment is presented in Figure 10.

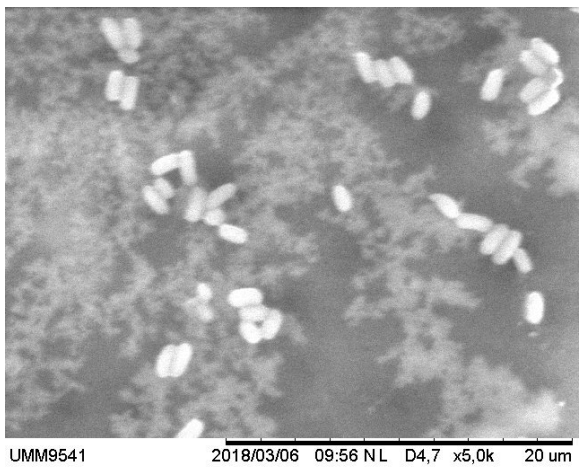

(a)

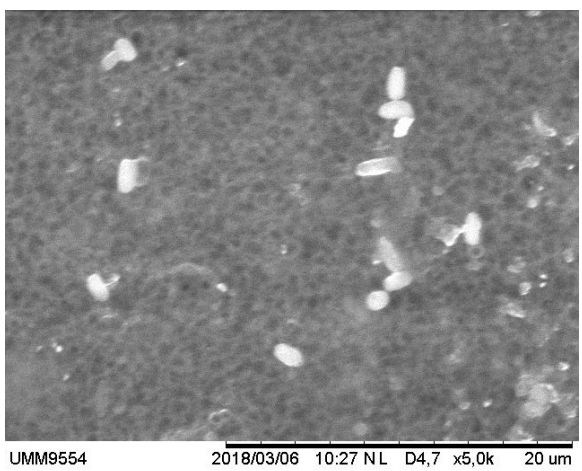

(c)

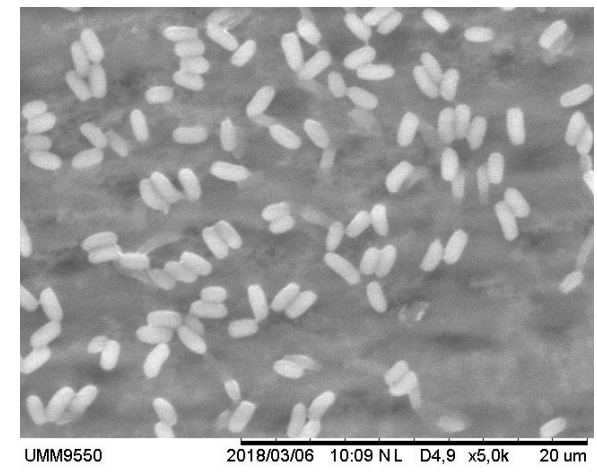

(b)

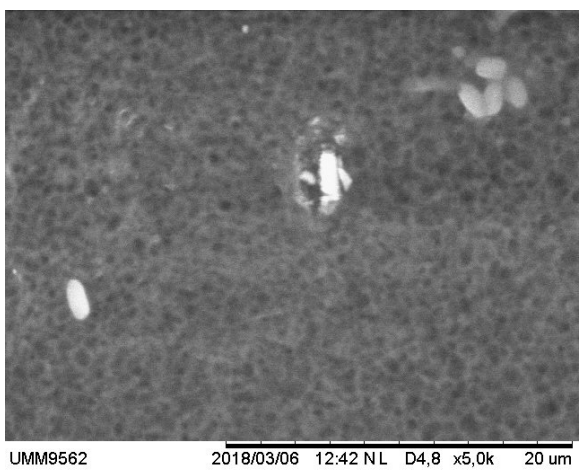

(d)

Figure 9. Membranes surface image using SEM after bacterial test. (a) Pristine membrane (made of DMF solvent), (b) Pristine membrane (made of DMAc solvent), (c) MMM with $1 \mathrm{wt} \%$ Moringa (made of DMF solvent), and (d) MMM with $1 \mathrm{wt} \%$ Moringa (made DMAc solvent). All SEM images used $5000 \times$ magnification. 


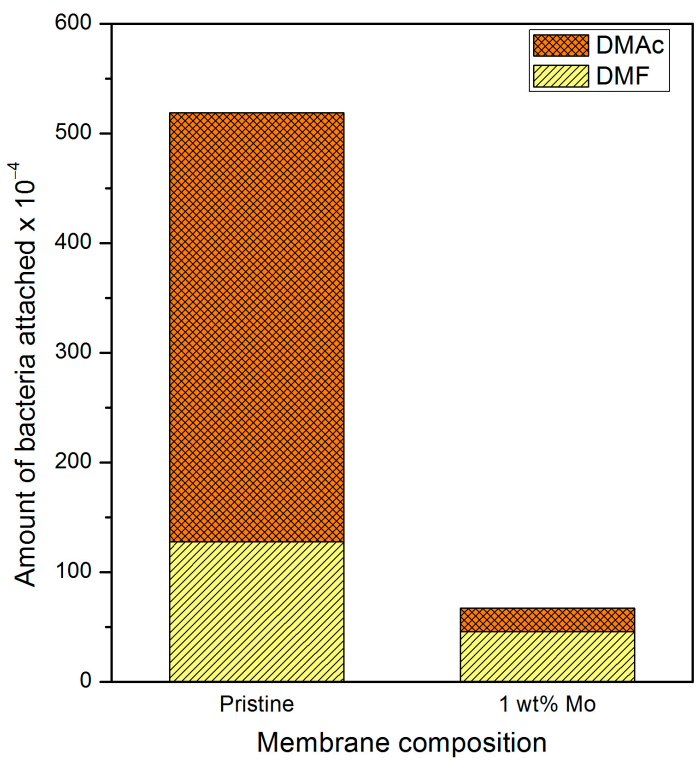

Figure 10. Amount of bacteria cells attached on membranes surfaces. The bacteria adhesion decreased due to the impregnation of Moringa seeds powder in the polymer matrix.

Based on Figure 10, the decrease of attachment of bacteria on membranes without Moringa seeds powder and the addition of $1 \mathrm{wt} \%$ Moringa seeds made of DMF solvent reached $64 \%$. While on the same ratio membrane made of DMAc solvent, the decrease of bacterial attachment of bacteria reached 95\%. According to Ferreira et al. [44], M. oleifera seeds powder inhibit the growth of bacteria and bacteriophages directly, and it clearly provides a similar effect on the MMM membranes.

Despite the positive impact of M. oleifera on anti-biofouling properties of MMMs, the dominant factors affecting the membrane properties is still unknown. Further study is required on the optimization of parameters, and some advance in the design of experiments (DoE) might be used, such as response surface methodology [45], two-level fractional factorial experiment [46], or Taguchi design of experiments [47].

\section{Conclusions}

Cellulose acetated based mixed matrix membranes containing a natural antibiofoulant $M$. oleifera seeds powder have been synthesized. Two different solvents were utilized, i.e., DMF and DMAc. The results show that the interaction of CA with DMAc solvent is more effective than with DMF solvent due to a higher solubility with CA. The interaction between DMAc solvent and CA resulted membranes with more macrovoid pores, when compared to membranes made of DMF solvent. The condition promotes that the membrane made of DMAc solvent has good permeability rather than that of the DMF solvent. MMMs with $1 \mathrm{wt} \%$ M. oleifera powder made of DMAc solvent has the highest value of clean water flux that is equal to $14,048 \mathrm{~L} \cdot \mathrm{m}^{-2} \cdot \mathrm{h}^{-1}$. M. oleifera powder works as an antibacterial and it can inhibit $E$. coli growth up to $64 \%$ and $95 \%$, respectively, in MMMs with $1 \mathrm{wt} \%$ M. oleifera seeds powder made of DMF and DMAc solvents, respectively. Thus, $M$. oleifera seeds can prevent biofouling in membrane processes, especially in being used for food processing.

Author Contributions: Y.W. was designing the concept and methods, P.A.R.U. and A.S. were responsible for experimentation processes, P.A.R.U. was writing original draft preparation, S.E.D., N.I. and Y.W. were conducting review and editing, and both Y.W. and S.S. were supervised the overall processes.

Funding: This study was founded by Ministry of Research, Technology and Higher Education, Republic of Indonesia through University Superior Applied Research Grant (PTUPT) scheme, year 2017-2018.

Acknowledgments: The author would like to thank Supriyono for facilitating the experimentation and Ashried Faradilla for helping during data collection.

Conflicts of Interest: The author declare no conflict of interest. 


\section{References}

1. Wibisono, Y. Two-Phase Flow for Fouling Control in Membranes. Ph.D. Thesis, University of Twente, Enschede, The Netherlands, 2014; p. 250.

2. Capannelli, G.; Bottino, A.; Munari, S.; Ballarino, G.; Mirzaian, H.; Rispoli, G.; Lister, G.; Maschio, G. Ultrafiltration of fresh orange and lemon juices. Lebensmittel-Wissenschaft Technologie 1992, 25, 518-522.

3. De Barros, S.T.D.; Andrade, C.M.G.; Mendes, E.S.; Peres, L. Study of fouling mechanism in pineapple juice clarification by ultrafiltration. J. Membr. Sci. 2003, 215, 213-224. [CrossRef]

4. Mondal, S.; Cassano, A.; Tasseli, F.; Sirshendu, D. A generalized model for clarification of fruit juice during ultrafiltration under total recycle and batch mode. J. Membr. Sci. 2011, 366, 295-303. [CrossRef]

5. Wibisono, Y.; Cornelissen, E.R.; Kemperman, A.J.B.; Nijmeijer, D.C.; Van der Meer, W.G.J. Influence of feed spacer geometries on air/water cleaning in spiral wound membrane elements. Procedia Eng. 2012, 44, 613-617. [CrossRef]

6. Wibisono, Y.; El Obied, K.E.; Cornelissen, E.R.; Kemperman, A.J.B.; Nijmeijer, K. Biofouling removal in spiral wound nanofiltration elements using two-phase flow cleaning. J. Membr. Sci. 2015, 475, 131-146. [CrossRef]

7. Wibisono, Y.; Yandi, W.; Golabi, M.; Nugraha, R.; Cornelissen, E.R.; Kemperman, A.J.B.; Ederth, T.; Nijmeijer, K. Hydrogel-coated feed spacers in two-phase flow cleaning in spiral wound membrane elements: A novel platform for eco-friendly biofouling mitigation. Water Res. 2015, 71, 171-186. [CrossRef] [PubMed]

8. Campbell, J.; Burgal, J.D.; Szekely, G.; Davies, R.P.; Braddock, D.C.; Livingston, A. Hybrid polymer/MOF membranes for Organic Solvent Nanofiltration (OSN): Chemical modification and the quest for perfection. J. Membr. Sci. 2016, 503, 166-176. [CrossRef]

9. Fei, F.; Cseri, L.; Szekely, G.; Blanford, C.F. Robust covalently cross-linked polybenzimidazole/graphene oxide membranes for high-flux organic solvent nanofiltration. ACS Appl. Mater. Interfaces 2018, 10, 16140-16147. [CrossRef]

10. Pal, A.; Dey, T.K.; Debnath, A.K.; Bhusan, B.; Sahu, A.K.; Bindal, R.C.; Kar, S. Mixed-matrix membranes with enhancing antifouling activity: Probing the surface-tailoring potential of Tiron and chromotropic acid for nano-TiO 2 . R. Soc. Open Sci. 2017, 4, 170368. [CrossRef]

11. Vatanpour, V.; Shockravi, A.; Zarrabi, H.; Nikjavan, Z.; Javandi, A. Fabrication and characterization of anti-fouling and anti-bacterial Ag-loaded graphene oxide/polyethersulfone mixed matrix membrane. J. Ind. Eng. Chem. 2015, 30, 342-352. [CrossRef]

12. Lim, M.Y.; Choi, Y.S.; Shin, H.; Kim, K.; Shin, D.M.; Lee, J.C. Cross-linked graphene oxide membrane functionalized with self-cross-linkable and bactericidal cardanol for oil/water separation. ACS Appl. Nano Mater. 2018, 1, 2600-2608. [CrossRef]

13. Viera, G.H.F.; Mourao, J.A.; Angelo, A.M.; Costa, R.A.; Fernandes, R.H.S. Antibacterial effect (in vitro) of Moringa oleifera and Annona muricata against Gram positive and Gram negative bacteria. Rev. Inst. Med. Trop. Sao Paulo 2010, 52, 129-132. [CrossRef]

14. Broin, M.; Santaella, C.; Cuine, S.; Kokou, K.; Peltier, G.; Joet, T. Flocculent activity of a recombinant protein from Moringa oleifera Lam seeds. Appl. Microbial. Biotechnol. 2002, 60, 114-119. [CrossRef]

15. Sun, X.; Lu, C.; Zhang, W.; Tian, D.; Zhang, X. Acetone-soluble cellulose acetate extracted from waste blended fabrics via ionic liquid catalyzed acetylation. Carbohyd. Polym. 2013, 98, 405-411. [CrossRef] [PubMed]

16. Yang, S.; Qinfeng, Z.; Tianhao, W.; Liping, Z. Effects of GO and MOF@GO on the permeation and antifouling properties of cellulose acetate ultrafiltration membrane. J. Membr. Sci. 2019, 569, 48-59. [CrossRef]

17. Abdellah, M.H.; Perez-Manriquez, L.; Puspasari, T.; Scholes, C.A.; Kentish, S.K.; Peinemann, K.V. A catechin/cellulose composite membrane for organic solvent nanofiltration. J. Membr. Sci. 2018, 567, 139-145. [CrossRef]

18. Colburn, A.; Wanninayake, N.; Kim, D.Y.; Bhattacharyya, D. Cellulose-graphene quantum dot composite membranes using ionic liquid. J. Membr. Sci. 2018, 556, 293-302. [CrossRef]

19. Ramirez, J.A.L.; Coello, O.M.D.; Quiroga, A.J.M. Comparative studies of reverse osmosis membranes for wastewater reclamation. Desalination 2006, 191, 137-147. [CrossRef]

20. Zularisam, A.W.; Ismail, A.F.; Salim, M.R.; Mimi, S.; Ozaki, H. The effects of natural organic matter (NOM) fractions on fouling characteristics and flux recovery of ultrafiltration membranes. Desalination 2007, 212, 191-208. [CrossRef] 
21. Boricha, A.G.; Murthy, Z.V.P. Preparation of N,O-carboxymethyl chitosan/cellulose acetate blend nanofiltration membrane and testing its performance in treating industrial wastewater. Chem. Eng. J. 2010, 157, 393-400. [CrossRef]

22. Saranya, R.G.A.; Ismail, A.F.; Dionysios, D.D.; Paul, D. Zero-valent iron impregnated cellulose acetate mixed matrix membranes for the treatment of textile industry effluent. RSC Adv. 2015, 5, 62486-62497. [CrossRef]

23. Dima, L.R.H. Uji aktivitas antibakteri ekstrak daun kelor (Moringa oleifera L.) terhadap bakteri Escherichia coli dan Staphylococcus aureus (in Bahasa Indonesia). Pharmacon 2016, 5, 282-289.

24. McLandsborough, L. Food Microbiology Laboratory; CRC Press: Boca Raton, FL, USA, 2003.

25. Wibisono, Y.; Faradilla, A.; Utoro, P.A.; Sukoyo, A.; Izza, N.; Dewi, S.R. Natural anti-biofoulant Moringa oleifera impregnated cellulose acetate mixed matrix membrane for juice clarification. J. Chem. Eng. Env. 2018, 13, 100-109.

26. Pratiwi, M.K.; Masyrifah, L.; Hawa, L.C.; Dewi, S.R.; Izza, N.; Argo, B.D.; Sucipto, S.; Wibisono, Y. Enhanced antibiofouling properties of chitosan-based membranes by coating and blending of Moringa oleifera L. extract. IOP Conf. Ser. Mater. Sci. Eng. 2018, 434, 012191. [CrossRef]

27. Camacho, F.P.; Bongiovani, M.C.; Silva, M.O.; Coldebella, P.F.; Amorim, M.T.; Bergamasco, R. Coagulation/flocculation/flotation/nanofiltration processes using Moringa oleifera as coagulant of eutrophized river. Chem. Eng. Trans. 2015, 43, 1123-1128. [CrossRef]

28. Singh, R.G.; Negi, P.S.; Radha, C. Phenolic composition, antioxidant and antimicrobial activities of free and bound phenolic extracts of Moringa oleifera seed flour. J. Funct. Foods 2013, 5, 1883-1891. [CrossRef]

29. Brandup. Handbook Polymer, 2nd ed.; John W \& Son: New York, NY, USA, 1975.

30. Mulder, M. Basic Principles of Membrane Technology; Kluwer Academic Publisher: Dordrecht, The Netherlands, 1996.

31. Xi, J.; Li, Z.; Yu, L.; Yin, B.; Wang, L.; Liu, L.; Qiu, X.; Chen, L. Effect of degree of sulfanation and casting solvent on sulfanated poly (ether ether ketone) membrane for vanadium redox flow battery. J. Power Sources 2015, 285, 195-204. [CrossRef]

32. Chakrabarty, B.; Ghshal, A.K.; Purkait, M.K. Effect of molecular weight of PEG on membrane morphology and transport properties. J. Membr. Sci. 2008, 309, 209-221. [CrossRef]

33. Liu, H.; Tang, C. Electrospinning of cellulose acetate in solvent mixture $N, N$-Dimethylacetamide (DMAc)/Acetone. Polym. J. 2007, 30, 65-72. [CrossRef]

34. Ahmad, A.; Waheed, S.; Khan, S.M.; Shafiq, M.; Farooq, M.; Sanaullah, K.; Jamil, T. Effect of silica on the properties of cellulose acetate/polyethylene glycol membranes for reverse osmosis. Desalination 2015, 355, 1-10. [CrossRef]

35. Chunyu, L.; Alejandro, S. Cohesive energy density and solubility parameter evolution during the curing of thermoset. Polymer 2018, 135, 162-170. [CrossRef]

36. Hildebrand, J.H.; Scott, R.L. The Solubility of Non-Electrolytes; Reinhold: New York, NY, USA, 1936.

37. Razali, M.; Didaskalou, C.; Kim, J.F.; Babaei, M.; Drioli, E.; Lee, Y.M.; Szekely, G. Exploring and exploiting the effect of solvent treatment in membrane separation. ACS Appl. Mater. Interfaces 2017, 9, 11279-11289. [CrossRef]

38. David, D.J.; Sincock, T.F. Estimation of miscibility of polymer blends using the solubility parameter concept. Polymer 1992, 33, 4505-4514. [CrossRef]

39. Sivakumar, M.; Mohan, D.R.; Rangarajan, R. Studies on cellulose acetate-polysulfone ultrafiltration membranes II. Effect of additive concentration. J. Membr. Sci. 2006, 268, 208-219. [CrossRef]

40. Ferreira, A.M.; Roque, E.B.; Da Fonseca, F.V.; Borges, C.P. High flux microfiltration membranes with silver nanoparticles for water disinfection. Desalin. Water Treat. 2015, 56, 3590-3598. [CrossRef]

41. Ariono, D.; Aryanti, P.T.P.; Subagjo, S.; Wenten, I.G. The effect of polymer concentration on flux stability of polysulfone membrane. AIP Conf. Proc. 2017, 1788, 030048. [CrossRef]

42. Miller, D.J.; Kasemset, S.; Paul, D.R.; Freeman, B.D. Comparison of membrane fouling at constant flux and constant transmembrane pressure conditions. J. Membr. Sci. 2013, 454, 505-515. [CrossRef]

43. Karim, Z.; Mathew, A.J.; Kokol, V.; Wei, J.; Grahn, M. High-flux affinity membranes based on cellulose nanocomposites for removal of heavy metal ions from industrial effluents. RSC Adv. 2016, 6, 20644-20653. [CrossRef] 
44. Ferreira, R.S.; Napoleao, T.H.; Santos, A.F.S.; Sa, R.A.; Carneiro-da-Cunha, M.G.; Morais, M.M.C.; Silva-Lucca, R.A.; Oliva, M.L.V.; Coelho, L.C.B.B.; Paiva, P.M.G. Coagulant and antibacterial activties of the water-soluble seed lectin from Moringa oeifera. Lett. Appl. Microbiol. 2011, 53, 186-192. [CrossRef] [PubMed]

45. Didaskalou, C.; Kupai, J.; Cseri, L.; Barabas, J.; Vass, E.; Holtzl, T.; Szekely, G. Membrane-grafted asymmetric organocatalyst for an integrated synthesis-separation platform. ACS Catal. 2018, 8, 7430-7438. [CrossRef]

46. Valtcheva, I.B.; Marchetti, P.; Livingston, A.G. Crosslinked polybenzimidazole membranes for organic solvent nanofiltration (OSN): Analysis of crosslinking reaction mechanism and effect of reaction parameters. J. Membr. Sci. 2015, 493, 568-579. [CrossRef]

47. Wibisono, Y.; Ahmad, F.; Cornelissen, E.R.; Kemperman, A.J.B.; Nijmeijer, K. Dominant factors controlling the efficiency of two-phase flow cleaning in spiral-wound membrane elements. Desalin. Water. Treat. 2016, 57, 17625-17636. [CrossRef]

(C) 2018 by the authors. Licensee MDPI, Basel, Switzerland. This article is an open access article distributed under the terms and conditions of the Creative Commons Attribution (CC BY) license (http:/ / creativecommons.org/licenses/by/4.0/). 